\title{
Quantitative effects of defaunation on rumen fermentation and digestion in sheep
}

\author{
BY J. B. ROWE*, A. DAVIES AND A. W. J. BROOME \\ Imperial Chemical Industries PLC, Pharmaceuticals Division, Alderley Park, \\ Macclesfield, Cheshire SK10 4TG
}

(Received 26 July 1984 - Accepted 25 January 1985)

1. Studies on the quantitative significance of protozoa on carbon and nitrogen digestion and metabolism in the rumen were carried out in sheep given a diet of pelleted concentrate $(500 \mathrm{~g} / \mathrm{d})$ and chopped hay $(500 \mathrm{~g} / \mathrm{d})$.

2. Measurements were made of apparent digestibility; flows of organic matter and dietary and microbial non-ammonia N (NAN) (using ${ }^{15} \mathrm{NH}_{4}^{+}$) to the duodenum; and rates of production, interconversion and metabolism of the major $\mathrm{C}$ fermentation end-products (from mathematical modelling of ${ }^{14} \mathrm{C}$ isotope values).

3. The population density of bacteria in the rumen increased as a result of defaunation ( 28.6 compared with $8.2 \times 10^{9}$ organisms $/ \mathrm{ml}$ ). This high density was associated with greater utilization of volatile fatty acids (VFA) within the rumen.

4. The rate of irreversible loss (IL) of bicarbonate + carbon dioxide from the rumen was greater in the defaunated animals $(98.5$ v. $57.2 \mathrm{~g} \mathrm{C} / \mathrm{d}$ ) but the IL from the blood was greater in the faunated group (138.6 v. $106.1 \mathrm{~g} \mathrm{C} / \mathrm{d}$ ). This is consistent with the hypothesis that the high population density of bacteria found in the rumen fluid of defaunated animals may result in increased fermentation of rumen VFA and digestible dietary carbohydrate, thereby increasing the output of $\mathrm{CO}_{2}$ from the rumen and reducing the quantity of VFA (hence energy) available to the host.

5. There was no difference in the flow of organic matter (OM) to the duodenum but there was a higher faecal excretion of $\mathrm{OM}$ in defaunated animals (apparent OM digestibility: 0.72 in faunated, 0.67 in defaunated).

6. Defaunation did not significantly increase the flow of NAN to the duodenum, the percentage of duodenal NAN of bacterial origin or the quantity of microbial NAN synthesized/g organic matter fermented. Faecal excretion of NAN was higher in defaunated animals $(5.3 v .3 .6 \mathrm{~g} \mathrm{~N} / \mathrm{d})$.

Experiments to investigate the role of protozoa in the nutrition of ruminants have provided equivocal evidence on their effect on growth rate and the concentration of rumen or blood metabolites (see Coleman, 1980). However, it has been suggested by Leng (1976) and Bergen \& Yokoyama (1977) that the major role of protozoa may be to reduce the availability of nutrients (principally protein) to the animal, since they engulf large numbers of bacteria and small feed-particles (Coleman, 1975) and are preferentially retained in the rumen (Weller \& Pilgrim, 1974; Harrison et al. 1979; Leng et al. 1981). It is interesting that improvements in live-weight gain and wool growth have only been shown to result from defaunation in animals given diets low in protein (Bird \& Leng, 1978; Bird et al. 1978). This is consistent with measurements made in in vitro fermentation studies of rumen microbial protein synthesis, where significant improvements were observed as a result of defaunation (Demeyer \& Van Nevel, 1979).

The experiments presented here were designed to measure the effect of defaunation on the efficiency of microbial protein synthesis in vivo and on the rates of production and utilization of the major rumen metabolites and blood carbon dioxide. In order to create the maximum possible difference in the rumen microbial population as a result of defaunation, care was taken to select a diet suitable for large ciliate protozoa and also to eliminate any side effects of the defaunating agent in the design of the experiment. A preliminary report of this experiment has already been published (Rowe et al. 1981).

\footnotetext{
* Present address: Department of Agriculture, Jarrah Road, South Perth, WA 6151, Australia.
} 


\section{MATERIALS AND METHODS}

\section{Experimental animals and diet}

Six mature wethers (35-40 kg) with permanent rumen and duodenal (' $T$ '-piece) cannulas were given a two-part diet, consisting of a pelleted concentrate (g/ $\mathrm{kg}$ : oats 450 , sucrose 230 , flaked maize 140, fishmeal 140, urea 26 , minerals and vitamins 14 ) fed at $500 \mathrm{~g} / \mathrm{d}$ with $500 \mathrm{~g}$ moderate quality $(90$ g crude protein (nitrogen $\times 6.25 ; \mathrm{CP}) / \mathrm{kg}$ and 0.58 in vitro digestibility) chopped hay/d for the duration of the experiment. The diet was given by a continuously moving belt, suspended above the animals, for 3 weeks before and during the period when measurements were made.

\section{Defaunation}

All the animals were defaunated by administering two doses $(8 \mathrm{~g} / \mathrm{dose})$ of 'Manoxal-OT' (dioctylsodium sulphosuccinate; BDH Chemicals Ltd, Poole, Dorset) on consecutive days, a procedure similar to that described by Orpin (1977) except that the animals were not starved beforehand. At 3 weeks after dosing, samples of rumen contents were examined microscopically to confirm the absence of protozoa. The animals were then divided into two groups of three and housed in separate rooms in metabolism pens. One group was uniformly re-inoculated with protozoa by transferring approximately $500 \mathrm{ml}$ rumen fluid from a ruminally cannulated steer into the rumen of each sheep. Samples of rumen fluid were taken (two per week) from each animal during the next 3 weeks to verify the absence of protozoa in the defaunated group and the stability of the protozoal population in the refaunated group. The precautions taken to avoid re-introduction of protozoa to the protozoa-free group included using separate lab coats when moving from one animal room to the other and rinsing hands in a solution of 'Manoxal-OT' in water $(4 \mathrm{~g} / \mathrm{l})$ before handling the defaunated animals.

\section{Experimental schedule}

The experimental measurements were made over a period of $17 \mathrm{~d}$ commencing 6 weeks after defaunation. Digestibility studies were conducted on days 1-7, during which time a mixture of $\mathrm{Cr}$ complexed with EDTA and the complex of $\mathrm{Ru}$-phenanthroline $(\mathrm{Ru}-\mathrm{P})$ were infused intraruminally. $\left({ }^{15} \mathrm{NH}_{4}\right)_{2} \mathrm{SO}_{4}$ was also infused intraruminally on days 4-7. On days 6 and 7 , samples of fluid-phase rumen microbes and duodenal digesta were taken. On day 11 each animal was prepared with a catheter in each jugular vein. From days 12 to 16 the rates of production of the major end-products of rumen fermentation, and also of blood bicarbonate $+\mathrm{CO}_{2}$, were measured by infusion of ${ }^{14} \mathrm{C}$-labelled metabolites. Samples of rumen fluid were taken on days 6,7 and $12-16$ for analysis of volatile fatty acids (VFA) and ammonia concentrations, in order to check for any major changes in the pattern of rumen fermentation between the experimental measurements and to estimate the population densities of bacteria and protozoa.

\section{Digestibility measurement}

Faeces and urine were collected separately over a $7 \mathrm{~d}$ period. Portions $(10 \%)$ of faeces and urine were taken from each daily collection, bulked and stored at $-20^{\circ}$ for analysis of dry matter (DM), organic matter (OM) and $\mathrm{N}$ by conventional techniques.

\section{Rumen and duodenal sampling}

Samples of rumen fluid were taken by suction via a probe with a perforated end which was moved through a number of sites in the rumen as each sample was withdrawn. Gas samples were taken through a similar movable plastic probe designed to pass through the cannula 
towards the dorsal surface of the rumen. Samples of duodenal digesta were collected into a plastic bag.

\section{Measurement of duodenal digesta flow rate and microbial protein synthesis}

CrEDTA (Binnerts et al. 1968) (130 mg Cr/l) and Ru-P (Tan et al. 1971) (11 mg Ru/l), were infused $(0.9 \mathrm{ml} / \mathrm{min})$ intraruminally as inert reference markers for the estimation of the flow of digesta to the small intestine. $\left({ }^{15} \mathrm{NH}_{4}\right)_{2} \mathrm{SO}_{4}$ was included in the infusate to provide approximately $0 \cdot 1 \mathrm{mg}{ }^{15} \mathrm{~N} / \mathrm{min}$ per sheep (Nolan \& Leng, 1972). Immediately following the collection of rumen fluid (approximately $50 \mathrm{ml}$ ), bacterial and protozoal fractions were isolated by differential centrifugation (Leng et al. 1981) for the analysis of ${ }^{15} \mathrm{~N}$ enrichment. Samples of duodenal digesta (approximately $200 \mathrm{ml}$ ) taken over a period of $0.25-0.5 \mathrm{~h}$ were prepared in the following way. Approximately $100 \mathrm{ml}$ was made alkaline $(\mathrm{pH} 8)$ with $2 \mathrm{M}$-sodium hydroxide and freeze-dried for the analysis of $\mathrm{Ru}, \mathrm{Cr}, \alpha$-linked glucose polymers (mainly starch) and non-ammonia-N (NAN). The NAN was retained as $\left(\mathrm{NH}_{4}\right)_{2} \mathrm{SO}_{4}$ for the measurement of ${ }^{15} \mathrm{~N}$ enrichment (see Nolan \& Leng, 1972). A further portion (approximately $10 \mathrm{ml}$ ) of duodenal digesta was centrifuged $(25000 \mathrm{~g}$ for $15 \mathrm{~min})$ and the supernatant fraction assayed for $\mathrm{Cr}, \mathrm{Ru}$ and NAN. The flow rate of digesta was estimated as described by Faichney (1975). The concentration of $\mathrm{Ru}$ in the fluid phase (supernatant fraction from high-speed centrifugation) was not measurable and was assumed to be zero in all calculations.

\section{Measurement of the rates of production of rumen $\mathrm{VFA}, \mathrm{CO}_{2}$ and methane}

Continuous infusions, each lasting $8 \mathrm{~h}$, were made on different days in the following order: $\mathrm{NaH}^{14} \mathrm{CO}_{3}$ (approximately $250 \mathrm{nCi} / \mathrm{ml}$ ); sodium [U-14 $\mathrm{C}$ ]acetate (approximately 100 $\mathrm{nCi} / \mathrm{ml}$ ); sodium $\left[2-{ }^{14} \mathrm{C}\right]$ propionate (approximately $100 \mathrm{nCi} / \mathrm{ml}$ ); sodium $\left[1-{ }^{14} \mathrm{C}\right]$ butyrate (approximately $100 \mathrm{nCi} / \mathrm{ml}$ ) intraruminally; and $\mathrm{NaH}^{14} \mathrm{CO}_{3}$ (approximately $1 \mu \mathrm{Ci} / \mathrm{ml}$ ) intravenously. Intraruminal infusions were at $0.9 \mathrm{ml} / \mathrm{min}$ and intravenous infusions at approximately $0.2 \mathrm{ml} / \mathrm{min}$. During the last $4 \mathrm{~h}$ of each infusion, samples of rumen fluid $(5 \mathrm{ml})$ were taken from each animal at intervals of $10 \mathrm{~min}$, the samples taken during each hour being acidified and stored in a single container for isolation of the VFA and analysis of their specific radioactivity (SR). Over the same period eight samples of blood and rumen fluid were taken at $0.5 \mathrm{~h}$ intervals to measure concentration and the SR of $\mathrm{HCO}_{3}^{-}+\mathrm{CO}_{2}$. Two samples of rumen gas (approx $50 \mathrm{ml}$ ) were taken 6.5 and $7.5 \mathrm{~h}$ after the start of each infusion to measure the $\mathrm{SR}$ of $\mathrm{CO}_{2}$ and $\mathrm{CH}_{4}$. Each gas sample was also analysed for $\mathrm{N}_{2}$, oxygen, $\mathrm{CH}_{4}$ and $\mathrm{CO}_{2}$ concentrations as a guide to the quantity of gas required for determination of the $\mathrm{SR}$ of $\mathrm{CO}_{2}$ and $\mathrm{CH}_{4}$ and to check for atmospheric contamination using the techniques of Czerkawski \& Clapperton (1968) as modified by Stanier \& Davies (1981).

\section{Determination of $\mathrm{SR}$ of $\mathrm{CO}_{2}$ and $\mathrm{CH}_{4}$}

Gas from the collecting syringe was transferred carefully to two more syringes (10 or $20 \mathrm{ml} /$ syringe depending on the content of $\mathrm{CO}_{2}$ and $\mathrm{CH}_{4}$ ). Carbonate-free $\mathrm{NaOH}$ solution $(1 \mathrm{M}, 3 \mathrm{ml}$ ) was then added through the syringe needle from a $5 \mathrm{ml}$ syringe via a short length of plastic tubing. Whilst still connected the pair of syringes were shaken vigorously for $1 \mathrm{~min}$ allowing the plunger of the larger syringe to move. The smaller syringe was removed and the larger one sealed by inserting its needle into a rubber bung. Between 10 and 20 min later this syringe was shaken for $2 \mathrm{~min}$. The $\mathrm{NaOH}$ solution was then cautiously expelled into a mixture of barium chloride $(100 \mathrm{~g} / 1,4 \mathrm{ml})$ and ammonium chloride $(100 \mathrm{~g} / 1,4 \mathrm{ml})$ solutions. Water $(3 \mathrm{ml})$ was added to the syringe which was rotated gently to pick up and substantially dilute residual $\mathrm{NaOH}$ solution. This water was added to the solution of 
$\mathrm{BaCl}_{2}+\mathrm{NH}_{4} \mathrm{Cl}$. The precipitated barium carbonate was filtered under vacuum through paper (Whatman no. 1; $25 \mathrm{~mm}$ diameter) held in a Millipore XX10 filter candle. Excess reagent was removed by washing with water (three portions of $10 \mathrm{ml}$ ) and acetone $(6 \mathrm{ml})$. The $\mathrm{BaCO}_{3}$ pellet was dried overnight at $60^{\circ}$ in an oven and then weighed into scintillation vials. All the $\mathrm{BaCO}_{3}$ was used when its weight was less than $40 \mathrm{mg}$, any excess over $40 \mathrm{mg}$ was removed.

To determine the $\mathrm{SR}$ of $\mathrm{CH}_{4}$ the residual gas in the syringe was injected manually at about $3 \mathrm{ml} / \mathrm{min}$ into a stream of $\mathrm{O}_{2}(10 \mathrm{ml} / \mathrm{min})$ and the mixed gas was passed through a silica tube $(300 \times 10 \mathrm{~mm})$ filled with cupric oxide (wire form, length $2-4 \mathrm{~mm}$ of approximately 28 standard wire gauge (swg); BDH micro analytical reagent) heated to approximately $900^{\circ}$ in a furnace. Effluent gas was mixed with carbonate-free $\mathrm{NaOH}$ solution $(1 \mathrm{M}, 2.5 \mathrm{ml} / \mathrm{min}$ ) and the mixture was passed through a thirty-turn glass spiral before passing into the base of a $150 \times 25 \mathrm{~mm}$ test-tube containing the solution of $\mathrm{BaCl}_{2}+\mathrm{NH}_{4} \mathrm{Cl}$ described previously. Thereafter the processing was as described for the determination of the $\mathrm{SR}$ of $\mathrm{CO}_{2}$.

\section{Measurement of $\mathrm{CH}_{4}$ production}

Daily $\mathrm{CH}_{4}$ production was measured using controlled air-flow feed boxes: $900 \mathrm{~mm} \times 600 \mathrm{~mm} \times 400 \mathrm{~mm}$. The front of the box was fitted with a canvas sleeve $350 \mathrm{~mm}$ in length, tapering from $250 \mathrm{~mm}$ diameter at the front of the box to $150 \mathrm{~mm}$. The open end of the sleeve was fitted with a draw cord which was used to pull the collar round the neck of the animal. Air was withdrawn from the box at 70 litres/min through a $15 \mathrm{~mm}$ (outside diameter) copper pipe by a mechanical pump (Edwards High Vacuum Ltd, UK). The volume extracted was measured in dry-gas meters (Thomas Glover and Son, UK). Close to the pump a sub-sample of gas was withdrawn through an 18 swg needle inserted into the main gas stream, into a butyl rubber bag (4 litres, BOC Medishield, UK) in a 5-litre aspirator jar. The latter was filled with water which was withdrawn at $2 \mathrm{ml} / \mathrm{min}$ by a peristaltic pump during gas sampling. The bag thus contained a subsample of approximately $3 \times 10^{-4}$ of the total gas drawn through the system. The total volume of $\mathrm{CH}_{4}$ eructated and expired by the animals was calculated from the total volume of gas displaced and the volumetric composition of the subsample, determined by gas-liquid chromatography using a glass column $(1.5 \mathrm{~m} \times 4 \mathrm{~mm})$ packed with Porapak $\mathrm{Q}$ (mesh 85/100) operated at room temperature using argon as the carrier $(50 \mathrm{ml} / \mathrm{min})$ and a flame ionization detector $\left(\mathrm{H}_{2}\right.$, $50 \mathrm{ml} / \mathrm{min}$; air, $300 \mathrm{ml} / \mathrm{min}$ ). Samples were read against a standard of $100 \mathrm{vol} / \mathrm{million} \mathrm{CH}_{4}$ in air (British Oxygen Company Special Gases, UK).

\section{Estimation of bacterial and protozoal population densities}

Samples of rumen fluid $(5 \mathrm{ml})$ were added to $20 \mathrm{ml}$ formal saline $(9 \mathrm{~g}$ sodium chloride $/ 1)$. Protozoa were counted in a standard counting chamber $0.2 \mathrm{~mm}$ deep (Hawksley, UK). Bacteria were counted following a further dilution of this sample (either 1:10 or 1:100) in a counting chamber $0.02 \mathrm{~mm}$ deep using a phase contrast microscope.

Three groups of protozoa were differentiated on the basis of size. Large organisms included mainly Isotricha and Epidinium spp., the medium size protozoa were principally Diplodinium and the small protozoa, Entodinia. Their volumes were estimated from the indings of Warner (1962). The volumes of the major bacterial groups were estimated from measurements of length and breadth using a microscope with calibrated eye piece.

\section{Chemical methods}

$\mathrm{Ru}$ and $\mathrm{Cr}$ concentrations in duodenal digesta were measured using an energy-dispersive X-ray analyser (model TEFA III; ORTEC, Tennessee, USA). Standards were made up in samples of duodenal fluid taken before the start of the infusion. 
Samples of duodenal supernatant fraction were analysed for $\mathrm{Cr}$ directly by atomic absorption spectrometry and read against standard solutions made up in pre-infusion samples of the same fluid. N concentrations were measured by distillation (Nolan \& Leng, 1972) following semi-microKjeldahl digestion where appropriate. ${ }^{15} \mathrm{~N}$ enrichment of rumen $\mathrm{NH}_{3}$, microbial and duodenal NAN was measured by mass spectrometry (model MS10; GEC-ACI Electronics, UK) (Nolan \& Leng, 1972).

The concentration of $\alpha$-linked glucose polymer (mainly starch) in freeze-dried duodenal digesta was measured by the method of MacRae \& Armstrong (1968).

The $\mathrm{SR}$ of rumen and blood $\mathrm{HCO}_{3}^{-}+\mathrm{CO}_{2}$ was measured as described by Leng \& Leonard (1965). The $\mathrm{BaCO}_{3}$ was suspended in a mixture of $10 \mathrm{ml}$ Instagel (Packard Instruments) and water $(4 \mathrm{ml})$ for counting. The SR of acetate, propionate and butyrate in rumen fluid were determined following liquid-liquid chromatographic separation of the acids (Rowe et al. 1982).

\section{Use of specifically labelled isotope tracers}

From the values obtained from intraruminal infusions of $\left[2-{ }^{14} \mathrm{C}\right]$ propionate and $\mathrm{H}^{14} \mathrm{CO}_{3}^{-}$, net fixation of $\mathrm{CO}_{2}$ into the carboxyl position of propionate has been observed (Mayes $e t$ al. 1981; Rowe et al. 1981) whereas from infusions of $\left[1-{ }^{14} \mathrm{C}\right]$ propionate, significant amounts of ${ }^{14} \mathrm{C}$ label are detected in the rumen $\mathrm{HCO}_{3}^{-}+\mathrm{CO}_{2}$ pool (Leng \& Leonard, 1965; Mayes et al. 1981). Both of these observations appear to be associated with the processes of carboxylation and decarboxylation during the synthesis of propionate via the succinate pathway. We used $\left[2{ }^{14} \mathrm{C}\right]$ propionate as a tracer, since it would be expected to give the more accurate indication of propionate production rate.

There appears to be no unrepresentative exchange of $\mathrm{C}$ between the carboxyl group of butyrate and the rumen $\mathrm{HCO}_{3}^{-}+\mathrm{CO}_{2}$ pool either in the synthesis of butyrate or in its conversion to acetate via the $\beta$-oxidation pathway (Leng, 1970). The readily available $\mathrm{n}-\left[1-{ }^{14} \mathrm{C}\right]$ butyric acid was therefore considered acceptable.

\section{Calculations}

The methods of mathematical analysis of the isotope-tracer results have been described previously by Nolan et al. (1976). The rates of irreversible loss (IL) of C from the primary (infusion) compartment were estimated as the rate of isotope infusion $(\mu \mathrm{Ci} / \mathrm{d})$ divided by the plateau SR $(\mu \mathrm{Ci} / \mathrm{g} \mathrm{C})$. The proportions of $\mathrm{C}$ in each of the secondary compartments derived from the primary compartment were estimated as the plateau SR of the secondary compartment divided by the plateau SR of the primary compartment. Assuming that the animal's metabolism was similar during each infusion, these sets of values were combined in a series of compartment models, using procedures outlined by Nolan et al. (1976), to give a unique solution for the flows of $\mathrm{C}$ into, out of and between the compartments considered. Where compartment models were used to measure specific pathways, separate solutions were obtained to the models for each individual animal, and treatment differences were tested for statistical significance using Student's $t$ test.

The proportion of microbial NAN was estimated as the ${ }^{15} \mathrm{~N}$ enrichment of whole digesta divided by the ${ }^{15} \mathrm{~N}$ enrichment of rumen bacteria. In the same way the proportion of bacterial $\mathrm{N}$ derived from rumen ammonia was estimated as the ${ }^{15} \mathrm{~N}$ enrichment of the bacterial $\mathrm{N}$ divided by the ${ }^{15} \mathrm{~N}$ enrichment of the rumen ammonia. Microbial OM flows were calculated assuming that $1 \mathrm{~g}$ microbial NAN is contained in $12 \mathrm{~g}$ microbial OM (Hungate, 1966). 
Table 1. Effect of defaunation on the distribution of microbial species in the rumen

\begin{tabular}{|c|c|c|c|c|c|}
\hline \multirow[b]{2}{*}{$\begin{array}{l}\text { Description of } \\
\text { microbial group }\end{array}$} & \multirow[b]{2}{*}{$\begin{array}{l}\text { Approximate } \\
\text { volume per } \\
\text { microbe }\left(\mu \mathrm{m}^{3}\right)\end{array}$} & \multicolumn{2}{|c|}{ Refaunated } & \multicolumn{2}{|c|}{ Defaunated } \\
\hline & & $\begin{array}{c}\text { Population } \\
\text { density } \\
\text { (organisms/ml } \\
\text { rumen fluid) }\end{array}$ & $\begin{array}{l}\text { Volume of } \\
\text { organisms } \\
\text { ( } \mu 1 / \mathrm{ml} \text { rumen } \\
\text { fluid) }\end{array}$ & $\begin{array}{c}\text { Population } \\
\text { density } \\
\text { (organisms } / \mathrm{ml} \\
\text { rumen fluid) }\end{array}$ & $\begin{array}{c}\text { Volume of } \\
\text { organisms } \\
(\mu \mathrm{l} / \mathrm{ml} \text { rumen } \\
\text { fluid) }\end{array}$ \\
\hline \multicolumn{6}{|l|}{ Small bacteria } \\
\hline Cocci & $1^{*}$ & $3.4 \times 10^{9}$ & 3.4 & $9.5 \times 10^{9}$ & $9 \cdot 5$ \\
\hline Vibrio & $5^{*}$ & $4.2 \times 10^{8}$ & $2 \cdot 2$ & $1.6 \times 10^{10}$ & $78 \cdot 5$ \\
\hline \multicolumn{6}{|l|}{ Large bacteria } \\
\hline Ovals & $20^{*}$ & $4.3 \times 10^{9}$ & $80 \cdot 6$ & $2.5 \times 10^{8}$ & $50 \cdot 0$ \\
\hline Rods & $100^{*}$ & $3.1 \times 10^{7}$ & $3 \cdot 1$ & $6.1 \times 10^{8}$ & $61 \cdot 0$ \\
\hline Total bacteria & & $8.2 \times 10^{9}$ & $89 \cdot 3$ & $28.6 \times 10^{9}$ & 199.0 \\
\hline \multicolumn{6}{|l|}{ Small protozoa } \\
\hline Entodinia & $10^{4} \dagger$ & $3.4 \times 10^{5}$ & $3 \cdot 4$ & - & - \\
\hline \multicolumn{6}{|l|}{ Medium protozoa } \\
\hline Diplodinium & $10^{5} \dagger$ & $7.8 \times 10^{4}$ & $7 \cdot 8$ & - & - \\
\hline \multicolumn{6}{|l|}{ Large protozoa } \\
\hline $\begin{array}{l}\text { Isotricha } \\
\text { Epidinium }\end{array}$ & $10^{8} \dagger$ & $5.2 \times 10^{4}$ & $52 \cdot 0$ & - & - \\
\hline Total protozoa & - & $4.7 \times 10^{5}$ & $63 \cdot 2$ & - & - \\
\hline Total biovolume & - & - & $152 \cdot 5$ & - & $199 \cdot 0$ \\
\hline
\end{tabular}

* Estimated by microscope with graduated eyepiece.

$\dagger$ Values of Warner et al. (1962).

\section{RESULTS}

\section{Rumen micro-organisms}

The defaunating treatment was fully effective and removed all protozoa from all animals as assessed by microscopical examination of liquid rumen contents. Defaunated animals remained protozoa-free throughout the experiment whilst the refaunated sheep attained stable protozoal populations before experimental measurements.

The total number of bacteria per unit volume of rumen fluid was significantly $(P<0 \cdot 01)$ higher in defaunated animals than in those with protozoa (Table 1). Similar morphological types of bacteria were seen in both groups but small cocci, rod or vibrio-shaped organisms predominated in defaunated animals while a higher proportion of large oval bacteria occurred in the refaunated group (Plate $1(a, b)$ ). The total volume of bacteria in the defaunated group (approximately $20 \%$ of total fluid volume) was about twice that in refaunated animals (approximately $9 \%$ ) and was also higher than the combined biovolume of both bacteria and protozoa (approximately 15\%) (Table 1).

\section{Metabolite concentrations}

The concentrations of total VFA, $\mathrm{HCO}_{3}^{-}+\mathrm{CO}_{2}$ and ammonia in rumen fluid and $\mathrm{HCO}_{3}^{-}+\mathrm{CO}_{2}$ in blood, measured throughout the experiment, are summarized in Table 2. Also shown are the molar proportions of individual VFA. There was generally less variation in each index measured in the eight samples taken from the same sheep on different days than between animals. No consistent changes in concentration were observed in any of the fermentation products during the series of ${ }^{14} \mathrm{C}$ and ${ }^{15} \mathrm{~N}$ infusions.

There were no significant changes in the molar proportions of individual VFA, due to defaunation. In the defaunated animals the concentration of $\mathrm{HCO}_{3}^{-}+\mathrm{CO}_{2}$ in rumen fluid was significantly $(P<0.01)$ higher than in the refaunated sheep. Rumen $\mathrm{pH}$ varied between 6.5 and 6.8 and did not vary in relation to time or experimental treatment. 
Table 2. The mean volatile fatty acid, bicarbonate + carbon dioxide, ammonia concentrations in rumen fluid, and $\mathrm{HCO}_{3}^{-}+\mathrm{CO}_{2}$ in blood, and the variability of the indices within individual animals and between animals during the experiment

\begin{tabular}{|c|c|c|c|c|c|c|c|}
\hline \multirow[b]{2}{*}{ Index } & \multirow[b]{2}{*}{$\begin{array}{c}\text { No. of } \\
\text { samples/ } \\
\text { sheep }\end{array}$} & \multicolumn{3}{|c|}{ Refaunated } & \multicolumn{3}{|c|}{ Defaunated } \\
\hline & & Mean & $\begin{array}{l}\text { Pooled } \\
\text { SE within } \\
\text { sheep }\end{array}$ & $\begin{array}{l}\text { SE }(n 3) \\
\text { between } \\
\text { sheep }\end{array}$ & Mean & $\begin{array}{l}\text { Pooled } \\
\text { SE within } \\
\text { sheep }\end{array}$ & $\begin{array}{c}\text { SE }\left(\begin{array}{ll}n & 3\end{array}\right) \\
\text { between } \\
\text { sheep }\end{array}$ \\
\hline $\begin{array}{l}\text { Total VFA concentration } \\
(\mathrm{mmol} / \mathrm{l})\end{array}$ & 8 & $76 \cdot 7$ & $5 \cdot 7$ & $2 \cdot 1$ & 88.9 & $5 \cdot 4$ & $12 \cdot 7$ \\
\hline \multicolumn{8}{|l|}{ Molar proportion $(\mathrm{mmol} / \mathrm{mol})$} \\
\hline Acetate & 8 & 611 & 9 & 14 & 575 & 12 & 14 \\
\hline Propionate & 8 & 247 & 10 & 15 & 229 & 9 & 24 \\
\hline Butyrate & 8 & 118 & 4 & 9 & 167 & 11 & 17 \\
\hline $\begin{array}{l}\mathrm{NH}_{3}-\mathrm{N} \text { concentration } \\
(\mathrm{mmol} / \mathrm{l})\end{array}$ & 8 & $6 \cdot 1$ & $0 \cdot 3$ & 0.8 & 6.1 & 0.5 & 0.3 \\
\hline Rumen $\mathrm{HCO}_{3}^{-}+\mathrm{CO}_{2}(\mathrm{mmol} / 1)$ & 12 & $2 \mathrm{I} \cdot 2^{* *}$ & $1 \cdot 1$ & 1.6 & $32 \cdot 5$ & 1.6 & 0.9 \\
\hline Blood $\mathrm{HCO}_{3}^{-}+\mathrm{CO}_{2}(\mathrm{mmol} / \mathrm{l})$ & 5 & $26 \cdot 3$ & 0.9 & $1 \cdot 2$ & $28 \cdot 7$ & 0.5 & $0 \cdot 3$ \\
\hline
\end{tabular}

Mean values were significantly different between refaunated and defaunated sheep: ** $P<0.01$.

\section{Quantitative changes in rumen fermentation}

The results of all measurements made from the continuous infusions of ${ }^{14} \mathrm{C}$-labelled compounds (VFA and $\mathrm{HCO}_{3}^{-}$intra-ruminally, and $\mathrm{HCO}_{3}^{-}$intravenously) are summarized in Table 3. Individual animal values are given in the appendix.

The mean SR of the $\mathrm{CO}_{2}$ in rumen gas samples was slightly lower than that of $\mathrm{HCO}_{3}^{-}+\mathrm{CO}_{2}$ from rumen fluid. The difference was not treatment related. Values presented in Table 3 are for samples taken from the liquid phase which is assumed to be in equilibrium with the metabolic pool, and for which more samples (nine fluid compared with two gas samples) were analysed, providing greater precision.

The IL and the proportional transfer of $\mathrm{C}$ from the primary infusion compartment to the secondary compartment are given for each treatment group. The largest differences in the pattern of rumen VFA production as a result of defaunation were in the IL of butyrate and the interconversion of $\mathrm{C}$ between acetate and butyrate. The IL of butyrate-C was significantly $(P<0.05)$ higher in the defaunated animals, with nearly $64 \%$ of this $C$ derived from acetate, compared with only $31 \%$ in the refaunated group. There was also a significantly $(P<0.01)$ higher proportion of acetate-C derived from butyrate in the defaunated animals (approximately 53\%) than in the refaunated sheep (approximately $18 \%)$. There was a significantly $(P<0.05)$ lower $\mathrm{IL}$ of blood $\mathrm{HCO}_{3}^{-}+\mathrm{CO}_{2}-\mathrm{C}$ and proportionally more blood $\mathrm{HCO}_{3}^{-}+\mathrm{CO}_{2}-\mathrm{C}$ derived from butyrate- $\mathrm{C}(P<0.05)$ in the defaunated group. There were no differences due to defaunation in the IL of methane although there was significantly $(P<0.05)$ less $\mathrm{CH}_{4}-\mathrm{C}$ derived from rumen $\mathrm{HCO}_{3}^{-}+\mathrm{CO}_{2}$ in animals with faunated rumen fluid. In refaunated sheep approximately half the $\mathrm{CH}_{4}$ was derived from $\mathrm{HCO}_{3}^{-}+\mathrm{CO}_{2}$ (mainly from the rumen), and the remainder directly from $\mathrm{C}$ which did not pass through the $\mathrm{HCO}_{3}^{-}+\mathrm{CO}_{2}$ compartment. In contrast, $80 \%$ of the $\mathrm{CH}_{4}$ was derived from rumen bicarbonate in defaunated sheep.

Calculations of production rates and the interconversion of $\mathrm{C}$ between metabolites were carried out using the values from Table 3 and applying the principle of compartmental analysis described by Nolan et al. (1976). The quantities of $\mathrm{C}$ oxidized to $\mathrm{CO}_{2}$ in the animal tissues and rumen were calculated from the two-compartment model: rumen $\mathrm{HCO}_{3}^{-}$and blood $\mathrm{HCO}_{3}^{-}$. In the refaunated animals the amount of $\mathrm{C}$ leaving the blood $\mathrm{HCO}_{3}^{-}+\mathrm{CO}_{2}$ 
Table 3. Summary of the rates of irreversible loss (IL) of the major end-products of rumen fermentation and blood bicarbonate + carbon dioxide measured in refaunated and defaunated sheep

(Also given are the percentage transfers of $\mathrm{C}$ between compartments. All values are the means of measurements of three sheep. Individual animal values are given in the appendix)

\begin{tabular}{|c|c|c|c|c|c|c|}
\hline \multirow[b]{2}{*}{ Compartment $i$} & \multicolumn{5}{|c|}{ Percentage of $i$ from } & \multirow{2}{*}{$\begin{array}{c}\mathrm{IL} \\
\text { (g C/d) of } \\
\text { compartment } i\end{array}$} \\
\hline & $\begin{array}{l}\text { Rumen } \\
\text { acetate }\end{array}$ & $\begin{array}{c}\text { Rumen } \\
\text { propionate }\end{array}$ & $\begin{array}{l}\text { Rumen } \\
\text { butyrate }\end{array}$ & $\stackrel{\text { Rumen }}{\mathrm{HCO}_{3}^{-}+\mathrm{CO}_{2}}$ & $\begin{array}{c}\text { Blood } \\
\mathrm{HCO}_{3}^{-}+\mathrm{CO}_{2}\end{array}$ & \\
\hline \multicolumn{7}{|c|}{ (a) Refaunated animals } \\
\hline \multicolumn{7}{|l|}{ Rumen } \\
\hline Acetate & - & $5 \cdot 0$ & $18 \cdot 1^{* *}$ & $5 \cdot 3$ & $2 \cdot 0$ & $58 \cdot 8$ \\
\hline Propionate & $10 \cdot 1$ & - & $5 \cdot 6$ & 31.8 & 8.9 & $59 \cdot 0$ \\
\hline Butyrate & $31 \cdot 0$ & $6 \cdot 5$ & - & 1.9 & $2 \cdot 1$ & $32 \cdot 2^{*}$ \\
\hline $\mathrm{HCO}_{3}^{-}+\mathrm{CO}_{2}$ & $10 \cdot 5$ & $3 \cdot 7$ & $7 \cdot 7$ & - & $26 \cdot 8$ & $57 \cdot 2$ \\
\hline Methane & 7.5 & $2 \cdot 8$ & $5 \cdot 4$ & $37 \cdot 0^{*}$ & $24 \cdot 7$ & 7.5 \\
\hline Blood $\mathrm{HCO}_{3}^{-}+\mathrm{CO}_{2}$ & $21 \cdot 0$ & $13 \cdot 8$ & $12 \cdot 8^{*}$ & $19 \cdot 3$ & - & $138 \cdot 6^{*}$ \\
\hline \multicolumn{7}{|c|}{ (b) Defaunated animals } \\
\hline \multicolumn{7}{|l|}{ Rumen } \\
\hline Acetate & - & $10 \cdot 0$ & 52.5 & $2 \cdot 2$ & $3 \cdot 4$ & $61 \cdot 4$ \\
\hline Propionate & 6.6 & - & $6 \cdot 5$ & $25 \cdot 7$ & $9 \cdot 2$ & $59 \cdot 5$ \\
\hline Butyrate & $63 \cdot 7$ & $10 \cdot 2$ & - & $1 \cdot 5$ & $2 \cdot 2$ & $49 \cdot 0$ \\
\hline $\mathrm{HCO}_{3}^{-}+\mathrm{CO}_{2}$ & $13 \cdot 6$ & $4 \cdot 3$ & $10 \cdot 4$ & - & $31 \cdot 0$ & $98 \cdot 5$ \\
\hline Methane & $8 \cdot 8$ & $3 \cdot 1$ & $8 \cdot 9$ & $80 \cdot 0$ & $25 \cdot 1$ & 6.0 \\
\hline Blood $\mathrm{HCO}_{3}^{-}+\mathrm{CO}_{2}$ & $24 \cdot 8$ & $12 \cdot 3$ & $20 \cdot 1$ & $20 \cdot 3$ & - & $106 \cdot 1$ \\
\hline
\end{tabular}

Mean values were significantly different between refaunated and defaunated animals: ${ }^{*} P<0 \cdot 05,{ }^{* *} P<0.01$.

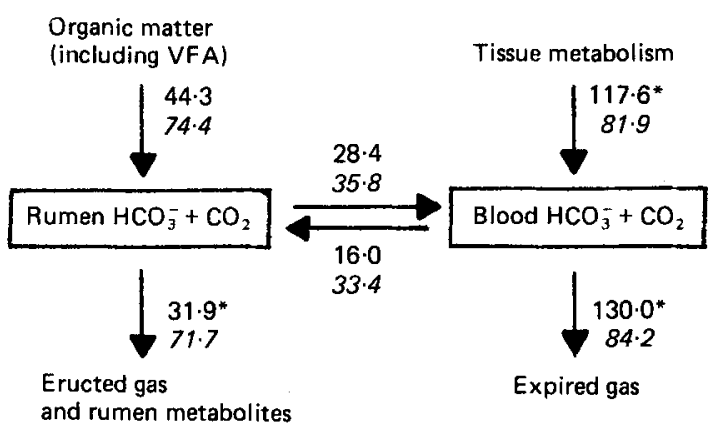

Fig. 1. Two-compartment model describing the production of bicarbonate + carbon dioxide in the rumen and tissues and the interconversion between these compartments. Flows are expressed as $\mathrm{g}$ carbon $/ \mathrm{d}$ with values measured in the defaunated animals given in italics. VFA, volatile fatty acids. Mean values were significantly different between refaunated and defaunated animals: ${ }^{*} P<0.05$.

compartment directly, $130.0 \mathrm{~g} \mathrm{C} / \mathrm{d}$, was significantly $(P<0.05)$ more than in the defaunated animals $\left(84.2 \mathrm{~g} \mathrm{C} / \mathrm{d} ; \mathrm{Fig}\right.$. 1). In the rumen there was a higher production of $\mathrm{HCO}_{3}^{-}+\mathrm{CO}_{2}$ in the absence of protozoa. The amount of $\mathrm{C}$ leaving the rumen $\mathrm{HCO}_{3}^{-}+\mathrm{CO}_{2}$ compartment in eructated gas and into rumen metabolites $(Y, \mathrm{~g} \mathrm{C} / \mathrm{d})$ measured in individual animals was closely related to the population density of bacteria $\left(X\right.$, bacteria $\left.\times 10^{9} / \mathrm{ml}\right)$ :

$$
Y=16 \cdot 4+19 \cdot 9 X, \quad\left(R^{2} 0.97, \text { residual SD } 4 \cdot 93\right) \text {. }
$$




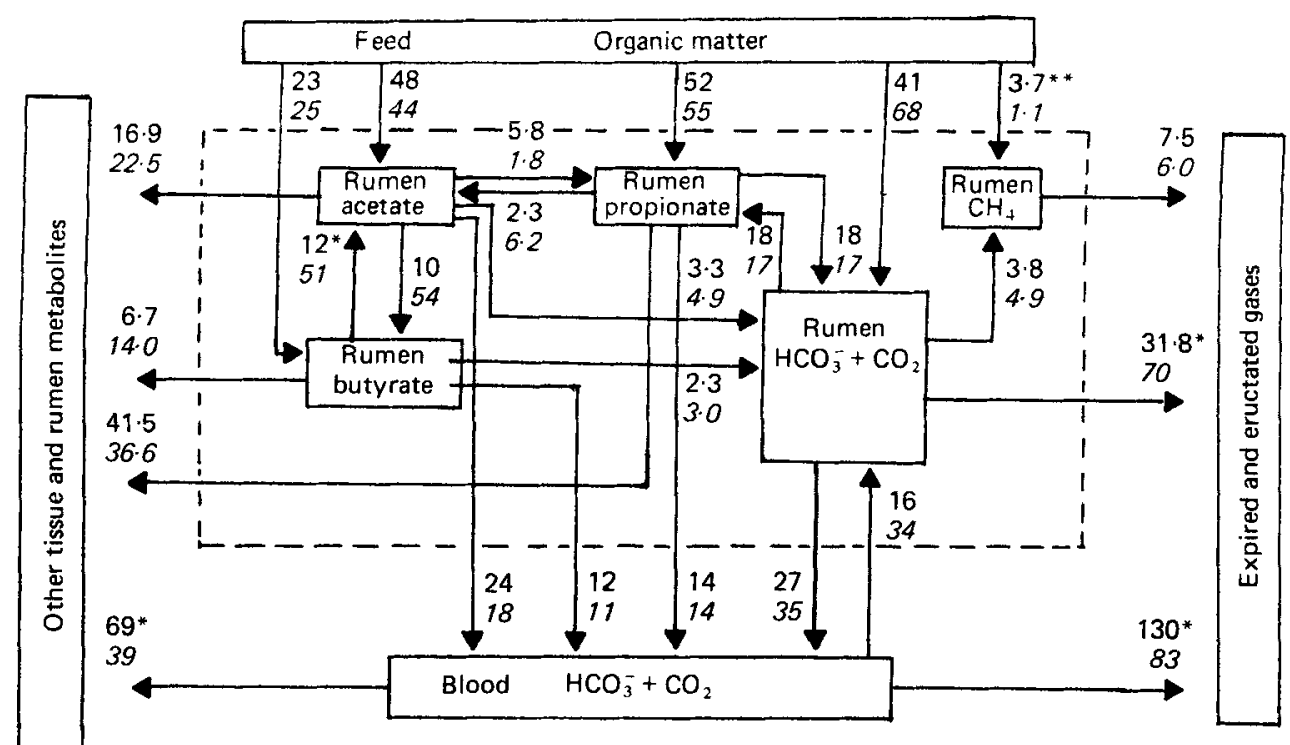

Fig. 2. Summary of the carbon flows measured between rumen volatile fatty acids, methane, bicarbonate + carbon dioxide and blood $\mathrm{HCO}_{3}^{-}+\mathrm{CO}_{2}$ using a series of three- and four-compartment models. The flow of $\mathrm{C}$ from rumen propionate to rumen $\mathrm{HCO}_{3}^{-}+\mathrm{CO}_{2}$ was made equal to the reverse flow on the basis of $\mathrm{HCO}_{3}^{-}+\mathrm{CO}_{2} \mathrm{C}$ equilibrating with the carboxyl group of propionate. This reciprocal flow was not measured by the $\left[2-{ }^{14} \mathrm{C}\right]$ propionate used as a tracer in this experiment. Flows are expressed as $\mathrm{g} \mathrm{C} / \mathrm{d}$ with values measured in the defaunated animals in italics. Mean values were significantly different between refaunated and defaunated animals: ${ }^{*} P<0.05,{ }^{* *} P<0.01$.

Flows of $C$ involved in rumen fermentation were calculated using a series of compartmental models. The four-compartment model: rumen acetate, propionate, butyrate and bicarbonate was used to account for all $\mathrm{C}$ flows between the major VFA and rumen $\mathrm{HCO}_{3}^{-}$but does not account for transfer of $\mathrm{C}$ between the rumen and the blood via $\mathrm{HCO}_{3}^{-}+\mathrm{CO}_{2}$. These values were provided from the three-compartment model: rumen propionate, rumen $\mathrm{HCO}_{3}^{-}$ and blood $\mathrm{HCO}_{3}^{-}$, and were confirmed (within limits of standard errors) by the fourcompartment model: rumen acetate, butyrate and $\mathrm{HCO}_{3}^{-}$and blood $\mathrm{HCO}_{3}^{-}$. The major aspects of rumen fermentation and utilization of end-products derived from these calculations are summarized in Fig. 2.

The extent of interconversion of $\mathrm{C}$ between acetate and butyrate was significantly $(P<0 \cdot 01)$ greater in the defaunated than in the refaunated animals, but the net effect was a change from a small synthesis of butyrate in the former into a small synthesis of acetate in the latter. The interconversion of $\mathrm{C}$ between acetate and butyrate $(Y, \mathrm{~g} \mathrm{C} / \mathrm{d})$ was related to the bacterial population density $\left(X\right.$, bacteria $\left.\times 10^{9} / \mathrm{ml}\right)$ as described by the following equation:

$$
Y=-11 \cdot 5+42 X, \quad\left(R^{2} 0 \cdot 76, \text { residual SD } 32\right) .
$$

The $\mathrm{C}$ source of $\mathrm{CH}_{4}$ was measured for each animal from values given in Table 3 using a four-compartment model: acetate, methane, rumen and blood $\mathrm{HCO}_{3}^{-}+\mathrm{CO}_{2}$. No infusion of ${ }^{14} \mathrm{CH}_{4}$ was made and, for the solution of the model, it was assumed that $\mathrm{CH}_{4}-\mathrm{C}$ was not converted to other forms of $\mathrm{C}$. There appeared to be almost no direct fermentation of acetate- $\mathrm{C}$ to $\mathrm{CH}_{4}$ in any animal $(0 \cdot 1-0 \cdot 2 \mathrm{~g} \mathrm{C} / \mathrm{d})$. 
Table 4. Apparent digestion of organic matter $(O M)$ in the forestomachs and whole digestive tract

(Also given is the flow of starch from the abomasum. Animals in both treatment groups ate $841 \mathrm{~g}$ $\mathrm{OM}$ and $159 \mathrm{~g}$ starch/d)

\begin{tabular}{|c|c|c|c|c|}
\hline & \multicolumn{2}{|c|}{ Refaunated } & \multicolumn{2}{|c|}{ Defaunated } \\
\hline & Mean & $\mathbf{S E}$ & Mean & SE \\
\hline $\begin{array}{l}\text { Duodenal flow } \\
\text { (g OM/d) } \\
\text { (g starch/d) }\end{array}$ & $\begin{array}{l}547 \\
14.5\end{array}$ & $\begin{array}{c}15 \\
3 \cdot 7\end{array}$ & $\begin{array}{l}568 \\
17 \cdot 3\end{array}$ & $\begin{array}{l}19 \\
2 \cdot 4\end{array}$ \\
\hline $\begin{array}{l}\text { Apparent loss of OM in forestomachs } \\
\text { calculated from } \\
\text { (1) Duodenal flow (g OM/d) } \\
\text { (2) Rumen VFA production (g OM/d) }\end{array}$ & $\begin{array}{l}281 \\
338\end{array}$ & $\begin{array}{l}13 \\
31\end{array}$ & $\begin{array}{l}271 \\
320\end{array}$ & $\begin{array}{r}7 \\
42\end{array}$ \\
\hline Apparent digestibility in whole tract & $0.72^{*}$ & 0.014 & 0.67 & 0.003 \\
\hline
\end{tabular}

Mean values were significantly different:* $P<0.05$.

Table 5. The apparent digestion of nitrogen and synthesis of microbial protein in sheep with faunated and defaunated rumen fluid

(The intake of both groups of animals was $25 \mathrm{~g} \mathrm{~N} / \mathrm{d}$ )

\begin{tabular}{|c|c|c|c|c|}
\hline \multirow[b]{2}{*}{ Index } & \multicolumn{2}{|c|}{ Faunated } & \multicolumn{2}{|c|}{ Defaunated } \\
\hline & Mean & SE & Mean & $\mathrm{SE}$ \\
\hline NAN flow to duodenum $(\mathrm{g} / \mathrm{d})$ & $19 \cdot 3 \dagger$ & $0 \cdot 23$ & $21 \cdot 9$ & $1 \cdot 36$ \\
\hline Faecal $N$ excretion $(g / d)$ & $3.6 \dagger$ & 0.21 & $5 \cdot 3$ & 0.75 \\
\hline $\begin{array}{l}\text { Rumen bacterial } \mathrm{N} \text { derived from rumen } \\
\mathrm{NH}_{3}(\%)\end{array}$ & $43 \dagger$ & $11 \cdot 2$ & 76 & $15 \cdot 8$ \\
\hline $\begin{array}{l}\text { Duodenal digesta NAN derived from } \\
\text { rumen bacteria }(\%)\end{array}$ & 65 & 4.9 & 68 & $7 \cdot 0$ \\
\hline Microbial NAN flow to duodenum $(\mathrm{g} / \mathrm{d})$ & $12 \cdot 3$ & 1.6 & $14 \cdot 8$ & $1 \cdot 11$ \\
\hline Microbial NAN (g)/kg FOM & 32 & $3 \cdot 2$ & 35 & $4 \cdot 60$ \\
\hline
\end{tabular}

NAN, non-ammonia-N; FOM, fermented organic matter (OM), i.e. OM apparently fermented in the forestomachs + microbial OM flow to the duodenum.

Mean values were significantly different: $\uparrow P<0 \cdot 10$.

\section{Digestion of $O M$ and $N$}

The intake and apparent digestion of $\mathrm{OM}$ and starch are given in Table 4. There were no differences which were statistically significant in the apparent digestion of OM or starch in the forestomachs as a result of defaunation. The apparent loss of OM in the rumen measured from the flow of OM to the duodenum was not significantly different from the amount of OM fermented to VFA in the rumen, measured using isotope-dilution techniques. There was a significant $(P<0.05)$ decrease in the apparent digestion of $\mathrm{OM}$ in the whole digestive tract as a result of defaunation.

The apparent digestion of $\mathrm{N}$ in the forestomachs and whole digestive tract is summarized in Table 5 together with measurements of the microbial protein synthesis. Flows of $\mathbf{N}$ are presented diagramatically in Fig. 3. In the defaunated animals there was a slightly $(P<0 \cdot 10)$ higher flow of $\mathrm{N}$ from the abomasum than in the refaunated sheep. In the 


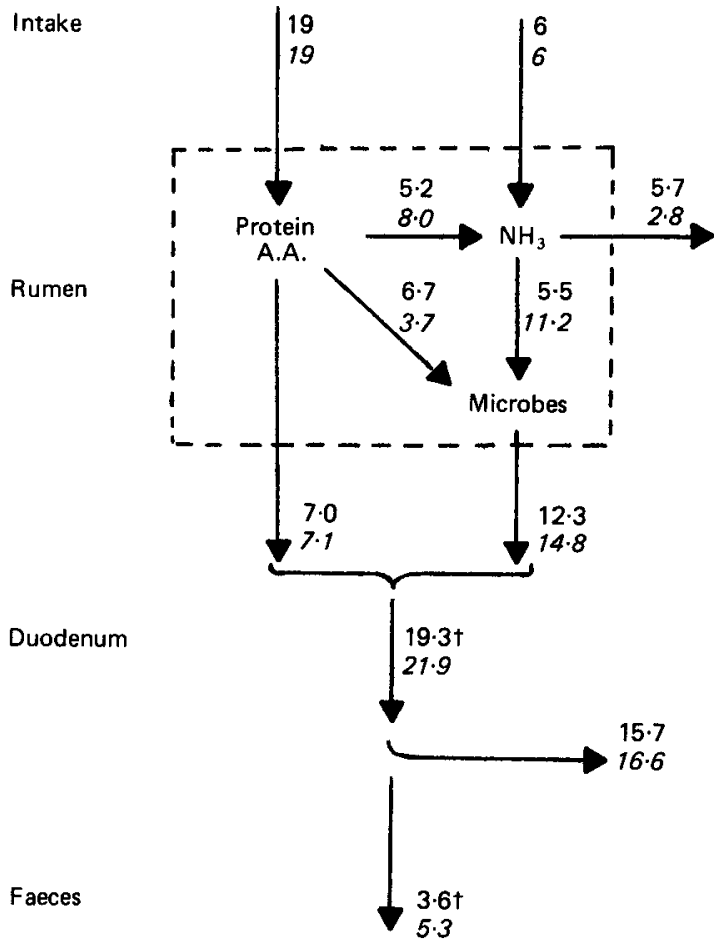

Fig. 3. Nitrogen flows (g N/d) measured in animals with faunated and defaunated rumen fluid. Separate models were calculated for individual animals, the flows being means for each treatment group. Measurements for defaunated animals are given in italics. Mean values were significantly different between refaunated and defaunated animals: $\uparrow P<0 \cdot 10$. A.A., amino acids.

defaunated animals the microbial utilization of rumen ammonia during growth was higher $(P<0 \cdot 10)$ than in the refaunated sheep, but the flow rate of microbial NAN from the abomasum was not significantly different. The incorporation of rumen ammonia in microbial protein $(Y, \mathrm{~g} \mathrm{~N} / \mathrm{d})$ was related to the bacterial population density ( $X$, bacteria $\times 10^{\circ} / \mathrm{ml}$ ) as described by the following equation:

$$
Y=2 \cdot 60+3 \cdot 23 X, \quad\left(R^{2} 0 \cdot 73, \text { residual sD } 2 \cdot 72\right) .
$$

The ${ }^{15} \mathrm{~N}$ enrichment of protozoa in the refaunated group was 31 (SE 9) \% of the rumen $\mathrm{NH}_{3}-\mathrm{N}$ and 70 (SE 6) \% of the rumen bacterial- $\mathrm{N}$ enrichment. Due to the three possible sources of protozoal $\mathrm{N}$ (rumen $\mathrm{NH}_{3}$, bacteria and dietary amino acids) and the single infusion of ${ }^{15} \mathrm{~N}$ tracer as $\mathrm{NH}_{3}$ into the rumen, it was not possible to measure the relative utilization of each $\mathrm{N}$ source in protozoal protein synthesis. The excretion of $\mathrm{N}$ in the faeces was apparently increased due to defaunation $(P<0 \cdot 10)$.

\section{DISCUSSION}

The most clearly defined difference resulting from defaunation was the change in the distribution of the rumen microbial species. The differences in the bacterial population density and species distribution observed in this experiment could not be attributed to the action of the defaunating agent (Manoxal-OT), since all animals received the same amount of detergent, at the same time. 
It is also unlikely that microbial populations in the refaunated animals were influenced by organisms introduced as protozoal inoculum with the rumen fluid used, since the donor animal was well adapted to a diet similar to that used in the present experiment. Thus it seems most likely that the observed differences in the microbial populations resulted principally from the presence or absence of protozoa. Coleman (1975) showed the capability of protozoa to ingest relatively large numbers of bacteria and it appears to be generally accepted that rumen fluid without the predatory protozoa is characterized by a higher population density of bacteria, irrespective of the method of defaunation (e.g. Eadie \& Gill, 1971; Kurihara et al. 1978; Demeyer \& Van Nevel, 1979).

In contrast to the findings of Eadie \& Gill (1971) and Whitelaw et al. (1983) that the ratio, butyrate: propionate was increased with the presence of protozoa, no significant changes were observed in the molar proportions of either acid in the present study, and IL of butyrate was significantly lower in the refaunated animals. It is likely that these differences in the pattern of VFA production, in response to defaunation, are related to differences in the diets. Diets used in the studies of Whitelaw et al. $(1972,1984)$ contained high levels of starch $(850 \mathrm{~g}$ barley $/ \mathrm{kg}$ diet $)$ whereas in the present experiment the diet contained significant quantities of sucrose and roughage in addition to starch. On the starch-based diets, $\mathrm{pH}$ was increased by the presence of protozoa and on this basis would be expected to decrease the molar proportion of propionate (Esdale \& Satter, 1972). No change in $\mathrm{pH}$ was obsarved in our experiment due to defaunation. In our study most of the increased butyrate production was from acetate and, since the extent of interconversion of $\mathrm{C}$ between acetate and butyrate was related to the population density of bacteria $\left(R^{2} 0 \cdot 76\right)$, it is suggested that the changes in VFA production observed were associated with increased bacterial competition for substrate rather than through a direct effect of protozoa.

The observation of increased production of rumen $\mathrm{HCO}_{3}^{-}$in the defaunated animals suggests the possibility of increased utilization of VFA and dietary carbohydrate in pathways other than those measured. There are two ways in which VFA potentially available for absorption may be used by the rumen micro-organisms: (1) acetogenic and methanogenic fermentations (see Bryant, 1979; Rowe et al. 1979), (2) utilization in the synthesis of structural or storage components during microbial cell synthesis, as discussed by Leng (1982). There was virtually no fermentation of acetate to methane in either treatment group in the present experiment; neither were there appreciable quantities of rumen $\mathrm{CO}_{2}$ derived directly from VFA. On the other hand, although no direct measurements of VFA incorporation into rumen microbes were made, it is likely that this would have been quantitatively important in the defaunated animals where the microbial biomass was significantly greater.

The increased concentration and IL of $\mathrm{HCO}_{3}^{-}+\mathrm{CO}_{2}$ in rumen fluid (by 50 and $70 \%$ respectively) and the decreased IL of $\mathrm{HCO}_{3}^{-}+\mathrm{CO}_{2}$ in the blood (23\%) indicate a change from oxidative energy metabolism at the tissue level towards oxidative fermentation in the rumen as a result of defaunation. The fact that the IL of $\mathrm{HCO}_{3}^{-}+\mathrm{CO}_{2}$ from the rumen was closely related $\left(R^{2} 0.97\right)$ to population density of bacteria, indicates that the extent of oxidative fermentation in the rumen may be affected by the size of the microbial population without altering the amount of substrate fermented. It appears that the increase in oxidative fermentation in the rumen may result in decreased oxidative tissue metabolism through less substrate being available in the animal, rather than the change in tissue $\mathrm{CO}_{2}$ output being caused by an increase in synthetic pathways in the defaunated sheep.

In the defaunated animals most of the $\mathrm{CH}_{4}-\mathrm{C}$ was derived from the $\mathrm{HCO}_{3}^{-}+\mathrm{CO}_{2}$ compartment (approximately $80 \%$ ) while in the faunated animals only about $50 \%$ of $^{-} \mathrm{CH}_{4}-\mathrm{C}$ was measured as passing through this pool. In view of the observations by Stumm et al. (1982) that certain methanogenic bacteria may be closely associated with rumen protozoa, 
it is possible that these bacteria may derive their $\mathrm{C}$ from the protozoa in a form not in equilibrium with the $\mathrm{HCO}_{3}^{-}+\mathrm{CO}_{2}$ pool in the rumen. The fact that $\mathrm{CH}_{4}$ production was not altered through defaunation is consistent with the similar rumen $\mathrm{pH}$ and propionate production in both groups of sheep and suggests that provided these indices remain constant the presence of protozoa does not affect methane production.

The proportion of $\mathrm{OM}$ apparently digested in the rumen estimated from the flow of $\mathrm{OM}$ to the duodenum ( 0.47 and 0.48 , for faunated and defaunated animals) was slightly lower than that observed using a range of similar diets (0.66-0.69) (Agricultural Research Council, 1980). While the same estimate made from the production of VFA in the rumen is not significantly higher $(0.56$ and 0.57$)$ it does suggest that the flow of organic matter to the duodenum may be slightly overestimated when 'cold' Ru-P and CrEDTA are used as inert markers for measuring digesta flow. When high concentrations of Ru-P are infused intra-ruminally there is significant adsorption of $\mathrm{Ru}$ on to the surface of the infusion lines and on to the rumen epithelium (J. B. Rowe and A. Davies, unpublished results), which would result in overestimation of duodenal flow rate. Samples were not taken to check for total faecal recovery of Ru but in other studies using 'cold' Ru-P and Cr EDTA, faecal recovery of Ru has apparently been less than $100 \%$ of that infused (J. D. Oldham, personal communication). This 'loss' of Ru on infusion lines and in the rumen could partially explain the difference between measurements of OM fermented in the rumen and total VFA production (Table 4).

The decreased OM digestibility in the whole tract, observed in the present study as a result of defaunation, is consistent with the findings of Klopfenstein et al. (1966) and Lindsay \& Hogan (1972). It appears therefore that while the rate of cellulose degradation in the rumen may actually be increased (Kurihara et al. 1978) and total VFA production unchanged (present study) by defaunation, the availability of energy to the animal may be decreased.

Many of the changes in the pattern of fermentation and oxidative metabolism were of the order of $30-70 \%$ whereas the effect of defaunation on protein availability appears to range between 7 and $13 \%$. Therefore, although protozoa have a potentially deleterious role in microbial protein synthesis through ingestion of large numbers of bacteria (Coleman, 1975) and subsequent retention of protein in the rumen (Weller and Pilgrim, 1974; Leng, 1982), this does not appear to be of major quantitative importance in reducing the amount of protein available to the animal. The relatively small increase in the availability of protein would therefore be expected to result in improvements in wool growth rate, feed intake and animal growth rate only in situations where the dietary protein concentration is sub-optimal.

Clearly, defaunation of rumen contents does not achieve any single change in the pattern of fermentation and digestion. The results of the present study support previous observations on the effects of defaunation, i.e. slightly reduced apparent digestibility of OM and a proliferation of rumen bacteria in the absence of protozoal predation. The increased production of rumen $\mathrm{CO}_{2}$ during rumen fermentation and the decreased amount of oxidative metabolism in the animal tissue, observed in the present study as a result of defaunation, may offer an explanation for the instances where animal performance, on diets adequate in protein, have been reduced. It therefore appears that in addition to the practical problems associated with defaunation and maintaining ruminants free of protozoa, the benefits of this potential management strategy may be limited to dietary situations characterized by sub-optimal protein levels.

The authors would like to thank Dr J. V. Nolan of the University of New England for analysis of ${ }^{15} \mathrm{~N}$ enrichment, and Messrs A. Norbury, P. Sambrook, G. Stanier and Mrs D. Lawson for their skilled technical assistance. 


\section{REFEREN CES}

Agricultural Research Council (1980). The Nutrient Requirements of Ruminant Livestock. Slough: Commonwealth Agricultural Bureaux.

Bergen, W. G. \& Yokoyama, M. T. (1977). Journal of Animal Science 46, 573-584.

Binnerts, W. J., Van't Klooster, A. Th. \& Frens, A. M. (1968). Veterinary Record 82, 470.

Bird, S. H., Baigent, D. R., Dixon, R. M. \& Leng, R. A. (1978). Proceedings of the Australian Society for Animal Production 12, 137.

Bird, S. H. \& Leng, R. A. (1978). British Journal of Nutrition 40, $163-167$.

Bryant, M. P. (1979). Journal of Animal Science 48, 193.

Coleman, G. S. (1975). In Digestion and Metabolism in the Ruminant, pp. 149-164 [I. W. McDonald and A. C. I. Warner, editors]. Armidale: University of New England Publishing Unit.

Coleman, G. S. (1980). Advances in Parasitology 18, 121-173.

Czerkawski, J. W. \& Clapperton, J. L. (1968). Laboratory Practice 17, 994-996.

Demeyer, D. I. \& Van Nevel, C. J. (1979). British Journal of Nutrition 42, 515-524.

Eadie, J. \& Gill, J. C. (1971). British Journal of Nutrition 26, 155-167.

Esdale, W. J. \& Satter, L. D. (1972). Journal of Dairy Science 55, 964-970.

Faichney, G. J. (1975). In Digestion and Metabolism in the Ruminant, pp 277-291 [I. W. McDonald and A. C. I. Warner, editors]. Armidale: University of New England Publishing Unit.

Harrison, D. G., Beever, D. E. \& Osbourne, D. F. (1979). British Journal of Nutrition 41, 521-527.

Hungate, R. E. (1966). The Rumen and its Microbes. New York: Academic Press.

Klopfenstein, T. J., Purser, D. B. \& Tyznik, W. J. (1966). Journal of Animal Science 25, 765-773.

Kurihara, Y., Takechi, T. \& Shibata, F. (1978). Journal of Agricultural Science, Cambridge 90, $373-381$.

Leng, R. A. (1970). In Physiology of Digestion and Metabolism in the Ruminant, pp. 406-421 [A. T. Philipson, editor]. Newcastle upon Tyne: Oriel Press.

Leng, R. A. (1976). In Reviews in Rural Science No. 2, From Plant to Animal Protein, pp. 85-91 [T. M. Sutherland, J. R. McWilliams and R. A. Leng, editors]. Armidale: University of New England Publishing Unit.

Leng, R. A. (1982). In Nutritional Limits to Animal Production from Pastures, pp. 427-453 [J. B. Hacker, editor]. Farnham Royal: Commonwealth Agricultural Bureaux.

Leng, R. A., Gill, M., Kempton, T. J., Rowe, J. B., Nolan, J. V., Stachiw, S. J. \& Preston, T. R. (1981). British Journal of Nutrition 46, 371-384.

Leng, R. A. \& Leonard, C. J. (1965). British Journal of Nutrition 19, 469-484.

Lindsay, J. R. \& Hogan, J. P. (1972). Australian Journal of Agricultural Research 23, 321-330.

MacRae, J. C. \& Armstrong, D. G. (1968). Journal of the Science of Food and Agriculture 19, 578-582.

Mayes, R. W., Milne, J. A., Lamb, C. S. \& Spence, A. M. (1981). Proceedings of the Nutrition Society 40, 9 A.

Nolan, J. V. \& Leng, R. A. (1972). British Journal of Nutrition 27, 177-194.

Nolan, J. V., Norton, B. W. \& Leng, R. A. (1976). British Journal of Nutrition 35, 127-147.

Orpin, C. G. (1977). Journal of Applied Bacteriology 43, 309-318.

Rowe, J. B., Davies, A. \& Broome, A. W. J. (1981). Proceedings of the Nutrition Society 40, 49 A.

Rowe, J. B., Davies, A., Hinchliffe, P. M. \& Broome, A. W. J. (1982). Laboratory Practice 31, $23-24$.

Rowe, J. B., Loughnan, M. L., Nolan, J. V. \& Leng, R. A. (1979). British Journal of Nutrition 41, $393-397$.

Stanier, G. \& Davies, A. (1981). British Journal of Nutrition 45, 567-578.

Stumm, C. K., Gijzen, H. J. \& Vogels, G. D. (1982). British Journal of Nutrition 47, $95-99$.

Tan, T. N., Weston, R. H. \& Hogan, J. P. (1971). International Journal of Radiation and Isotopes 22, 301-308.

Warner, A. C. I. (1962). Journal of General Microbiology 28, 129-146.

Weller, R. A. \& Pilgrim, A. F. (1974). British Journal of Nutrition 32, 341-351.

Whitelaw, F. G., Eadie, M. J., Bruce, L. A. \& Shand, W. J. (1983). Proceedings of the Nutrition Society 42, 158 A.

Whitelaw, F. G., Eadie, M. J., Bruce, L. A. \& Shand, W. J. (1984). British Journal of Nutrition 52, $261-275$.

Whitelaw, F. G., Eadie, M. J., Mann, S. O. \& Reid, R. S. (1972). British Journal of Nutrition 27, $425-437$.

\section{EXPLANATION OF PLATE}

Plate 1. Photomicrographs of rumen fluid taken from sheep with $(a)$ faunated rumen fluid and $(b)$ defaunated rumen fluid. The dilution, 1 part rumen fluid: 4 parts formal saline ( $9 \mathrm{~g}$ sodium chloride/ 1 ) was the same for both samples. 

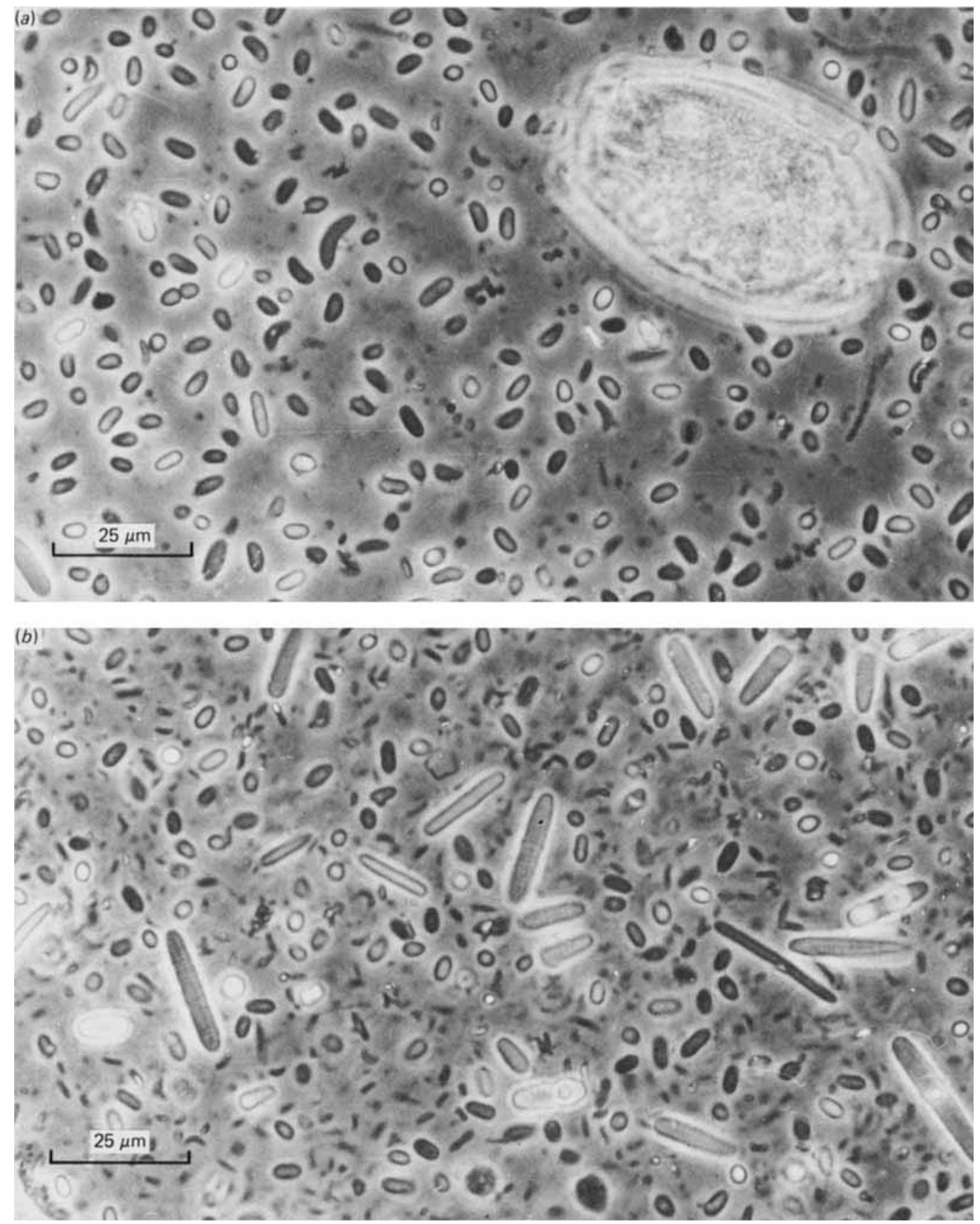
Appendix. Summary of the rates of irreversible loss $(I L)$ of the major end-products of rumen fermentation and blood bicarbonate + carbon dioxide measured in refaunated and defaunated sheep

(Also given are the percentage transfers of carbon between compartments)

\begin{tabular}{|c|c|c|c|c|c|c|c|}
\hline \multirow[b]{2}{*}{ Compartment $i$} & \multirow[b]{2}{*}{ Animal } & \multicolumn{5}{|c|}{ Percentage of $i$ from } & \multirow{2}{*}{$\begin{array}{c}\mathrm{IL} \\
\text { compartment } i\end{array}$} \\
\hline & & $\begin{array}{l}\text { Rumen } \\
\text { acetate }\end{array}$ & $\begin{array}{c}\text { Rumen } \\
\text { propionate }\end{array}$ & $\begin{array}{l}\text { Rumen } \\
\text { butyrate }\end{array}$ & $\underset{\mathrm{HCO}_{3}^{-}+\mathrm{CO}_{2}}{\text { Rumen }}$ & $\begin{array}{c}\text { Blood } \\
\mathrm{HCO}_{3}^{-}+\mathrm{CO}_{2}\end{array}$ & \\
\hline \multicolumn{8}{|c|}{ (a) Refaunated animals } \\
\hline $\begin{array}{l}\text { Rumen } \\
\text { acetate } \\
\text { Mean }\end{array}$ & $\begin{array}{l}1 \\
2 \\
3\end{array}$ & $\begin{array}{l}- \\
- \\
-\end{array}$ & $\begin{array}{l}5 \cdot 0 \\
5 \cdot 3 \\
4 \cdot 6 \\
5 \cdot 0\end{array}$ & $\begin{array}{l}20 \cdot 4 \\
21 \cdot 0 \\
12 \cdot 8 \\
18 \cdot 1^{* *}\end{array}$ & $\begin{array}{l}7 \cdot 0 \\
7 \cdot 0 \\
2 \cdot 0 \\
5 \cdot 3\end{array}$ & $\begin{array}{l}2 \cdot 0 \\
2 \cdot 1 \\
2 \cdot 0 \\
2 \cdot 0\end{array}$ & $\begin{array}{l}78 \cdot 7 \\
52 \cdot 4 \\
45 \cdot 4 \\
58 \cdot 8\end{array}$ \\
\hline $\begin{array}{l}\text { Rumen } \\
\text { propionate } \\
\text { Mean }\end{array}$ & $\begin{array}{l}1 \\
2 \\
3\end{array}$ & $\begin{array}{r}12 \cdot 6 \\
8 \cdot 7 \\
9 \cdot 1 \\
10 \cdot 1\end{array}$ & $\begin{array}{l}- \\
- \\
-\end{array}$ & $\begin{array}{l}4 \cdot 1 \\
6 \cdot 4 \\
6 \cdot 2 \\
5 \cdot 6\end{array}$ & $\begin{array}{l}25 \cdot 5 \\
34 \cdot 0 \\
36 \cdot 0 \\
31 \cdot 8\end{array}$ & $\begin{array}{l}7 \cdot 8 \\
9 \cdot 0 \\
9 \cdot 8 \\
8 \cdot 9\end{array}$ & $\begin{array}{l}86 \cdot 9 \\
66 \cdot 2 \\
23 \cdot 8 \\
59 \cdot 0\end{array}$ \\
\hline $\begin{array}{c}\text { Rumen } \\
\text { butyrate } \\
\text { Mean }\end{array}$ & $\begin{array}{l}1 \\
2 \\
3\end{array}$ & $\begin{array}{l}41 \cdot 4 \\
21 \cdot 0 \\
28 \cdot 0 \\
31 \cdot 0\end{array}$ & $\begin{array}{l}8 \cdot 2 \\
7 \cdot 4 \\
3 \cdot 8 \\
6 \cdot 5\end{array}$ & $\begin{array}{l}- \\
- \\
-\end{array}$ & $\begin{array}{l}2 \cdot 5 \\
2 \cdot 0 \\
1 \cdot 2 \\
1.9\end{array}$ & $\begin{array}{l}1 \cdot 5 \\
2 \cdot 9 \\
2 \cdot 0 \\
2 \cdot 1\end{array}$ & $\begin{array}{l}32 \cdot 3 \\
27 \cdot 9 \\
36 \cdot 3 \\
32 \cdot 2^{*}\end{array}$ \\
\hline $\begin{array}{l}\underset{\mathrm{HCO}_{3}^{-}}{\text {Rumen }}+\mathrm{CO}_{2} \\
\text { Mean }\end{array}$ & $\begin{array}{l}1 \\
2 \\
3\end{array}$ & $\begin{array}{r}15 \cdot 0 \\
9 \cdot 2 \\
7 \cdot 3 \\
10 \cdot 5\end{array}$ & $\begin{array}{l}6 \cdot 0 \\
3 \cdot 6 \\
1 \cdot 4 \\
3 \cdot 7\end{array}$ & $\begin{array}{l}8 \cdot 0 \\
6 \cdot 2 \\
8 \cdot 8 \\
7 \cdot 7\end{array}$ & $\begin{array}{l}- \\
- \\
-\end{array}$ & $\begin{array}{l}31 \cdot 3 \\
27 \cdot 9 \\
21 \cdot 3 \\
26 \cdot 8\end{array}$ & $\begin{array}{l}52 \cdot 8 \\
59 \cdot 9 \\
58.9 \\
57 \cdot 2\end{array}$ \\
\hline $\begin{array}{c}\text { Rumen } \\
\text { methane } \\
\text { Mean }\end{array}$ & $\begin{array}{l}1 \\
2 \\
3\end{array}$ & $\begin{array}{r}11 \cdot 0 \\
5 \cdot 1 \\
6 \cdot 4 \\
7 \cdot 5\end{array}$ & $\begin{array}{l}3 \cdot 9 \\
3 \cdot 1 \\
1 \cdot 3 \\
2 \cdot 8\end{array}$ & $\begin{array}{l}5 \cdot 5 \\
4 \cdot 0 \\
6 \cdot 7 \\
5 \cdot 4\end{array}$ & $\begin{array}{l}49 \cdot 0 \\
31 \cdot 0 \\
31 \cdot 0 \\
37 \cdot 0^{*}\end{array}$ & $\begin{array}{l}25 \cdot 7 \\
27 \cdot 0 \\
21 \cdot 3 \\
24 \cdot 7\end{array}$ & $\begin{array}{l}9 \cdot 1 \\
7 \cdot 7 \\
5 \cdot 7 \\
7 \cdot 5\end{array}$ \\
\hline $\begin{array}{l}\text { Blood } \\
\mathrm{HCO}_{3}^{-}+\mathrm{CO}_{2} \\
\text { Mean }\end{array}$ & $\begin{array}{l}1 \\
2 \\
3\end{array}$ & $\begin{array}{l}30 \cdot 0 \\
16 \cdot 0 \\
17 \cdot 0 \\
21 \cdot 0\end{array}$ & $\begin{array}{r}5 \cdot 3 \\
14 \cdot 0 \\
22 \cdot 0 \\
13 \cdot 8\end{array}$ & $\begin{array}{l}13 \cdot 1 \\
10 \cdot 0 \\
15 \cdot 2 \\
12 \cdot 8^{*}\end{array}$ & $\begin{array}{l}18 \cdot 0 \\
18 \cdot 0 \\
22 \cdot 0 \\
19 \cdot 3\end{array}$ & $\begin{array}{l}- \\
-\end{array}$ & $\begin{array}{l}122 \cdot 0 \\
146 \cdot 7 \\
147 \cdot 1 \\
138.6^{*}\end{array}$ \\
\hline \multicolumn{8}{|c|}{ (b) Defaunated animals } \\
\hline $\begin{array}{c}\text { Rumen } \\
\text { acetate } \\
\text { Mean }\end{array}$ & $\begin{array}{l}4 \\
5 \\
6\end{array}$ & $\begin{array}{l}- \\
- \\
-\end{array}$ & $\begin{array}{r}3 \cdot 6 \\
15 \cdot 5 \\
11 \cdot 0 \\
10 \cdot 0\end{array}$ & $\begin{array}{l}61.4 \\
55 \cdot 0 \\
41 \cdot 0 \\
52.5\end{array}$ & $\begin{array}{l}2 \cdot 0 \\
2 \cdot 5 \\
2 \cdot 0 \\
2 \cdot 2\end{array}$ & $\begin{array}{l}4 \cdot 3 \\
2 \cdot 2 \\
3 \cdot 6 \\
3 \cdot 4\end{array}$ & $\begin{array}{l}45 \cdot 6 \\
74 \cdot 6 \\
64 \cdot 1 \\
61 \cdot 4\end{array}$ \\
\hline $\begin{array}{l}\text { Rumen } \\
\text { propionate } \\
\text { Mean }\end{array}$ & $\begin{array}{l}4 \\
5 \\
6\end{array}$ & $\begin{array}{r}10 \cdot 0 \\
6 \cdot 1 \\
3 \cdot 7 \\
6 \cdot 6\end{array}$ & $\begin{array}{l}- \\
- \\
-\end{array}$ & $\begin{array}{l}7 \cdot 1 \\
6 \cdot 0 \\
6 \cdot 4 \\
6 \cdot 5\end{array}$ & $\begin{array}{l}24 \cdot 0 \\
32 \cdot 0 \\
21 \cdot 0 \\
25 \cdot 7\end{array}$ & $\begin{array}{r}9 \cdot 2 \\
7 \cdot 4 \\
10 \cdot 9 \\
9 \cdot 2\end{array}$ & $\begin{array}{l}37 \cdot 7 \\
86 \cdot 9 \\
53 \cdot 8 \\
59 \cdot 5\end{array}$ \\
\hline $\begin{array}{c}\text { Rumen } \\
\text { butyrate } \\
\text { Mean }\end{array}$ & $\begin{array}{l}4 \\
5 \\
6\end{array}$ & $\begin{array}{l}59 \cdot 0 \\
87 \cdot 0 \\
45 \cdot 0 \\
63 \cdot 7\end{array}$ & $\begin{array}{r}8 \cdot 8 \\
14 \cdot 5 \\
7 \cdot 4 \\
10 \cdot 2\end{array}$ & $\begin{array}{l}- \\
- \\
-\end{array}$ & $\begin{array}{l}1.0 \\
2 \cdot 0 \\
1 \cdot 5 \\
1 \cdot 5\end{array}$ & $\begin{array}{l}2 \cdot 5 \\
1 \cdot 7 \\
2 \cdot 4 \\
2 \cdot 2\end{array}$ & $\begin{array}{l}53 \cdot 4 \\
54 \cdot 2 \\
39 \cdot 5 \\
49 \cdot 0^{*}\end{array}$ \\
\hline$\stackrel{\text { Rumen }}{\mathrm{HCO}_{3}^{-}}+\mathrm{CO}_{2}$ & $\begin{array}{l}4 \\
5 \\
6\end{array}$ & $\begin{array}{r}9 \cdot 8 \\
19 \cdot 0 \\
12 \cdot 0 \\
13 \cdot 6\end{array}$ & $\begin{array}{l}2 \cdot 3 \\
7 \cdot 2 \\
3 \cdot 5 \\
4 \cdot 3\end{array}$ & $\begin{array}{r}11 \cdot 4 \\
13 \cdot 4 \\
6 \cdot 4 \\
10 \cdot 4\end{array}$ & $\begin{array}{l}- \\
- \\
-\end{array}$ & $\begin{array}{l}25 \cdot 0 \\
34 \cdot 6 \\
33 \cdot 3 \\
31 \cdot 0\end{array}$ & $\begin{array}{r}106 \cdot 8 \\
120 \cdot 0 \\
68 \cdot 7 \\
98 \cdot 5\end{array}$ \\
\hline $\begin{array}{l}\text { Rumen } \\
\text { methane }\end{array}$ & $\begin{array}{l}4 \\
5 \\
6\end{array}$ & $\begin{array}{r}6 \cdot 4 \\
11 \cdot 0 \\
9.0 \\
8.8\end{array}$ & $\begin{array}{l}1 \cdot 8 \\
6 \cdot 0 \\
2 \cdot 6 \\
3 \cdot 1\end{array}$ & $\begin{array}{r}9 \cdot 5 \\
10 \cdot 6 \\
6 \cdot 6 \\
8.9\end{array}$ & $\begin{array}{l}75 \cdot 0 \\
95 \cdot 0 \\
70 \cdot 0 \\
80 \cdot 0^{*}\end{array}$ & $\begin{array}{l}22 \cdot 6 \\
29 \cdot 4 \\
23 \cdot 2 \\
25 \cdot 1\end{array}$ & $\begin{array}{l}6 \cdot 3 \\
5 \cdot 8 \\
6 \cdot 0 \\
6 \cdot 0\end{array}$ \\
\hline $\begin{array}{l}\underset{\mathrm{HCO}_{3}^{-}}{\text {Blood }}+\mathrm{CO}_{2} \\
\text { Mean }\end{array}$ & $\begin{array}{l}4 \\
5 \\
6\end{array}$ & $\begin{array}{l}18 \cdot 3 \\
31 \cdot 0 \\
25 \cdot 0 \\
24 \cdot 8\end{array}$ & $\begin{array}{r}6 \cdot 9 \\
18 \cdot 0 \\
12 \cdot 0 \\
12 \cdot 3\end{array}$ & $\begin{array}{l}21 \cdot 9 \\
21 \cdot 8 \\
16 \cdot 7 \\
20 \cdot 1^{*}\end{array}$ & $\begin{array}{l}25 \cdot 0 \\
44 \cdot 0 \\
19 \cdot 0 \\
29 \cdot 3\end{array}$ & $\begin{array}{l}- \\
-\end{array}$ & $\begin{array}{c}92 \cdot 2 \\
116 \cdot 5 \\
109 \cdot 6 \\
106 \cdot 1^{*}\end{array}$ \\
\hline
\end{tabular}

Mean values were significantly different between refaunated and defaunated animals: ${ }^{*} P<0.05,{ }^{* *} P<0.01$. 